\title{
EFEKTIFITAS PEMBERIAN WEDANG JAHE TERHADAP FREKUENSI MUAL DAN MUNTAH PADA IBU HAMIL TRIMESTER I DI KABUPATEN BENGKULU UTARA TAHUN 2017
}

\author{
Iluh Meta Indrayani, Rialike Burhan, Desi Widiyanti \\ Poltekkes Kemenkes Bengkulu \\ e-mail: metaindrayani@gmail.com
}

\begin{abstract}
Emesis gravidarum is a usual complaint that is often experienced by the first trimester pregnant women, and coul develop become hyperemesis gravidarum thus increasing the risk of pregnancy. Ginger is kind of herbs which has been known to prevent nausea vomiting. The purpose of this study is the effectiveness of giving wedang ginger to the frequency of nausea and vomiting in pregnant women trimester I. The design of this research is Quasi experiment with One Group Pre test-Post test design. The sampling technique used purposive sampling with the sample of 10 first trimester pregnant women who experience emesis gravidarum. This research was conducted at Work Area of Air Lais Puskesmas of North Bengkulu Regency on January 5, 2018 until February 6, 2018. Analysis of difference of frequency of nausea vomiting before and after intervention using Paired Sample T-Test. The results of this study indicate the average frequency of nausea vomiting pregnant women trimester I before given wedang ginger of 9.30. While the average frequency of nausea vomiting trimester pregnant women I after given ginger wedang of 4.50. The result of bivariate analysis showed that there was difference of mean of nausea vomiting frequency before and after intervention of wedang ginger equal to 4,80 with $p=0.000$. Expected for the community can take advantage of ginger wedang as an alternative treatment before using antiemetic drugs, and can process other variants of ginger plants that can be used to lower the emesis gravidarum frequency.
\end{abstract}

Keyword : Wedang Ginger, Emesis Gravidarum

\section{ABSTRAK}

Emesis gravidarum merupakan keluhan normal yang sering dialami ibu hamil trimester pertama, dan dapat menjadi hiperemesis gravidarum sehingga meningkatkan risiko terjadinya gangguan kehamilan. Jahe merupakan tanaman herbal yang sudah sejak lama dikenal untuk mencegah mual muntah. Tujuan dari penelitian ini adalah efektifitas pemberian wedang jahe terhadap frekuensi mual dan muntah pada ibu hamil trimester I. Desain penelitian ini adalah Quasi eksperiment dengan rancangan One Group Pre test-Post test. Teknik pengambilan sampel menggunakan purposive sampling dengan sampel sebanyak 10 ibu hamil trimester pertama yang mengalami emesis gravidarum. Penelitian ini dilakukan di Wilayah Kerja Puskesmas Air Lais Kabupaten Bengkulu Utara pada tanggal 5 Januari 2018 sampai dengan 6 Februari 2018. Analisis perbedaan frekuensi mual muntah sebelum dan sesudah intervensi menggunakan Paired Sample T-Test. Hasil penelitian ini menunjukkan rata-rata frekuensi mual muntah ibu hamil trimester I sebelum diberikan wedang jahe sebesar 9,30. Sedangkan rata-rata frekuensi mual muntah ibu hamil trimester I setelah diberikan wedang jahe sebesar 4,50. Hasil analisis bivariat menunjukkan ada perbedaan rata-rata frekuensi mual muntah sebelum dan sesudah intervensi wedang jahe sebesar 4,80 dengan p=0,000. Diharapkan bagi masyarakat dapat memanfaatkan wedang jahe sebagai pengobatan alternatif sebelum 
Iluh Meta I, Rialike B, dan Desi W, Efektifitas Pemberian Wedang Jahe terhadap Frekuensi Mual dan Muntah pada Ibu Hamil Trimester I di Kabupaten Bengkulu Utara Tahun 2017

menggunakan obat antiemetik, dan dapat mengolah varian lain dari tanaman jahe yang dapat digunakan untuk menurunkan frekuensi emesis gravidarum.

Kata kunci : Wedang Jahe, Emesis Gravidarum

\section{PENDAHULUAN}

Emesis gravidarum merupakan mual muntah yang muncul pada empat minggu pertama kehamilan dan perlahan menghilang pada umur kehamilan menginjak dua belas minggu (Purwaningsih, 2010). Mual didefinisikan sebagai kecendrungan memuntahkan sesuatu, atau sensasi yang muncul pada daerah kerongkongan atau epigastrik tanpa diikuti dengan muntah, sedangkan muntah didefinisikan sebagai pengeluaran isi lambung melalui mulut, dan umumnya disertai dengan dorongan yang kuat yang terjadi pada kehamilan (Setiawan, 2012).

Prevalensi emesis gravidarum di Indonesia juga berbeda-beda disetiap daerah. Elsa dkk (2012) menunjukkan kejadian emesis gravidarum pada ibu hamil trimester I di Boyolali sebesar $42,86 \%$. Selanjutnya, Rinata dkk (2015) melaporkan bahwa sebagian besar (60\%) ibu hamil di sidoarjo mengalami emesis gravidarum. Marianti dkk (2014) juga melaporkan bahwa sebanyak 27 orang $(71,1 \%)$ ibu hamil di Pekanbaru mengalami emesis gravidarum.

Emesis gravidarum dalam keadaan normal tidak banyak menimbulkan efek negatif, hanya saja apabila emesis gravidarum berkelanjutan menjadi hiperemesis gravidarum akan membawa resiko yang terjadinya gangguan pada kehamilan misalnya dehidrasi, pasien dapat mengalami syok, menghambat tumbuh kembang janin, gangguan keseimbangan elektrolit, cadangan karbohidrat dalam tubuh ibu akan habis, robekan pada selaput jaringan esophagus dan lambung dapat terjadi bila muntah terlalu sering dan memiliki resiko yang lebih tinggi untuk melahirkan bayi dengan berat badan lahir rendah, prematur, dan nilai apgar kurang dari tujuh (Manuaba, 2012).

Penanganan emesis gravidarum dibagi menjadi farmakologi dan non farmakologi. Penanganan secara farmakologi terdiri dari pemberian Vitamin yang (vitamin B kompleks, mediamer N6 sebagai vitamin dan anti muntah) dan pengobatan sedatif ringan. Penanganan non farmakologi untuk mengatasi emesis gravidarum misalnya dengan cara memberikan teh panas (Bandiyah, 2009) dan memberikan jahe (Setiwan, 2012).

Jahe merupakan tanaman obat dan juga rempah-rempah yang sudah lama dikenal oleh masyarakat Indonesia. jahe hampir tersebar diseluruh daerah tropika basah di Kawasan Asia. Sentrum utama tanaman jahe di Indonesia adalah Sumatera Utara, Bengkulu, Jawa Barat, Jawa Tengah, dan Jawa Timur (Setyaningrum, 2013). Jahe dapat mengendurkan dan melemahkan otot-otot saluran pencernaan sehingga mual dan muntah 
dapat berkurang (Glare et al, 2011 dan Perwitasari et al, 2011) .

Penelitian yang dilakukan Putri, dkk (2017) sebelum diberi intervensi rata-rata responden mengalami frekuensi mual muntah sebanyak 13 kali dalam sehari, setelah diberi intervensi minuman jahe hangat rata-rata frekuensi mual muntah menurun menjadi 3,18 kali dalam sehari. Penelitian Hasanah (2014) menunjukkan bahwa ada perbedaan yang signifikan penurunan frekuensi emesis gravidarum setelah diberikan wedang jahe.

Data yang didapatkan dari Dinas Kesehatan Kabupaten Bengkulu Utara pada tahun 2016 Puskesmas Air Lais merupakan Puskesmas dengan jumlah ibu hamil terbanyak sebanyak 697 ibu hamil dengan cakupan K1 sebesar 78\% (Dinas Kesehatan Kabupaten Bengkulu Utara, 2016). Dan Puskesmas Perumnas dengan jumlah ibu hamil terbanyak kedua. Data rekapan register pemeriksaan ibu hamil di Puskesmas Air Lais tahun 2016 didapatkan bahwa hamil trimester I yang memeriksakan dirinya ke Puskesmas dengan keluhan mual muntah sebanyak 83 orang $(11,9 \%)$. Selanjutnya, jumlah ibu hamil di Puskesmas Lais tahun 2017 berjumlah 697 orang dengan cakupan K1 sebesar 77,51 dan Puskesmas Perumnas jumlah ibu hamil tahun 2017 berjumlah 576. Data rekapan register pemeriksaan ibu hamil di Puskesmas Air Lais tahun 2017 didapatkan bahwa hamil trimester I yang memeriksakan dirinya ke Puskesmas dengan keluhan mual muntah 95 orang (13, $6 \%$ ) mengeluhkan mual muntah.

Bidan di Puskesmas dalam menangani mual muntah memberikan asuhan berupa konseling kepada ibu hamil dan memberikan vitamin B6 yang efektif untuk mengurangi mual muntah. Survey awal yang dilakukan di Puskesmas Air Lais pada 10 orang ibu hamil trimester I yang memeriksakan diri ke Puskesmas Air Lais, 8 orang dari mereka mengeluhkan mual muntah di pagi hari.

Hasil wawancara pada 8 orang ibu yang mengalami mual muntah, obat yang diberikan Bidan untuk mengatasi mual dan muntah kepada ibu tidak diminum secara teratur dikarenakan mual muntah yang dialami ibu. Selanjutnya, ibu belum pernah mengkonsumsi wedang jahe untuk mengatasi mual muntah. Sehingga, perlu diadakannya penelitian mengenai efektifitas pemberian wedang jahe terhadap frekuensi mual dan muntah pada ibu hamil trimester I di Kabupaten Bengkulu Utara Tahun 2017

\section{METODE PENELITIAN}

Metode dalam penelitian ini adalah Quasi Eksperimen dengan rancangan One Group Pre test-Post test. Variabel dalam penelitian ini adalah variabel independen (pemberian wedang jahe) dan variabel dependen (frekuensi mual dan muntah). Jenis jahe yang digunakan yaitu jahe merah dengan pemberian satu gelas pada pagi dan satu gelas pada sohe hari. 
Sampel penelitian ini berjumlah 10 orang ibu hamil trimester I yang diambil dari rumus Sopiyudin Dahlan (2016)). Kriteria inklusi: Ibu bersedia menjadi responden, primigravida, trimester I umur kehamilan 0-12 minggu, Ibu hamil yang mengalami mual muntah fisiologis. Kriteria ekslusi: Ibu hamil yang mempunyai penyakit gangguan mental, Ibu hamil dengan gastritis, hiperemesis gravidarum, kelainan ginjal, kelainan hati, diabetes melitus dan riwayat obstetri jelek (abortus, riwayat SC).

Instrumen dalam penelitian ini ialah kuesioner karakteristik dan lembar Pregnancy Unique Quantification of Emesis and Nausea (PUQE).
Teknik pengumpulan data adalah data primer yang diperoleh langsung dari responden. Penelitian ini dilakukan dari hari ke-1 sampai dengan hari ke-4. Pengumpulan data dilakukan dengan mengambil data primer yaitu karakteristik (umur, pendidikan, pekerjaan dan umur kehamilan) lembar Pregnancy Unique Quantification of Emesis and Nausea (PUQE) (frekuensi mual muntah sebelum dan sesudah diberikan wedang jahe). Penelitian ini menggunakan analisis univariat, analisis bivariat (uji paired sampel t-test).

\section{HASIL DAN PEMBAHASAN}

1. Analisi Univariat Karakteristik Responde

Tabel 1. Distribusi Frekuensi Karakteristik Umur, Pendidikan, Pekerjaan dan Umur Kehamilan di Kabupaten Bengkulu Utara Tahun 2017

\begin{tabular}{llcc}
\hline No & Karakteristik Responden & $\begin{array}{c}\text { Frekuensi } \\
(\mathbf{n = 1 0})\end{array}$ & $\begin{array}{c}\text { Persentase } \\
(\mathbf{1 0 0 \% )})\end{array}$ \\
\hline $\mathbf{1}$ & $\begin{array}{l}\text { Umur } \\
\text { <20 tahun dan }>35 \text { tahun }\end{array}$ & 1 & 10 \\
\hline & 20-35 tahun & 9 & 90 \\
\hline $\mathbf{2}$ & Pendidikan & & 30 \\
\hline & Rendah & 3 & 70 \\
\hline$\quad$ Tinggi & 7 & 70 \\
\hline $\mathbf{3}$ & Pekerjaan & & 30 \\
\hline & Tidak Bekerja & 7 & \\
\hline & Bekerja & 3 & 40 \\
\hline $\mathbf{4}$ & Umur Kehamilan & & 60 \\
\hline & 4-8 minggu & 4 & \\
\hline
\end{tabular}

Berdasarkan tabel 1 diatas, semua umur responden berada dalam usia reproduksi sehat $(100 \%)$ dan sebagian besar responden berpendidikan tinggi (70\%) dan tidak bekerja $(70 \%)$. Serta umur kehamilan dalam rentang 812 minggu (60\%). 
2. Distribusi frekuensi Mual dan Muntah

Tabel 2. Distribusi Frekuensi Mual dan Muntah Sebelum dan Sesudah diberikan Wedang Jahe di Kabupaten Bengkulu Utara Tahun 2017

\begin{tabular}{|c|c|c|c|}
\hline No & $\begin{array}{c}\text { Frekuensi Mual dan } \\
\text { Muntah (skor PUQE) }\end{array}$ & $\begin{array}{c}\begin{array}{c}\text { Frekuensi } \\
(\mathbf{n}=10)\end{array} \\
\end{array}$ & Persentase (100\%) \\
\hline \multirow[t]{4}{*}{1} & Sebelum & & \\
\hline & Emesis Ringan $(\leq 6)$ & 2 & 20 \\
\hline & Emesis Sedang (7-12) & 6 & 60 \\
\hline & Emesis Berat (13-15) & 2 & 20 \\
\hline \multirow[t]{4}{*}{2} & Sesudah & & \\
\hline & Emesis Ringan $(\leq 6)$ & 8 & 80 \\
\hline & Emesis Sedang (7-12) & 2 & 20 \\
\hline & Emesis Berat (13-15) & 0 & 0 \\
\hline
\end{tabular}

Berdasarkan tabel 2 di atas, presentase tertinggi frekuensi mual dan muntah sebelum dilakukan pemberian wedang jahe dalam kategori emesis sedang yaitu sebesar (60\%) dan frekuensi tertinggi setelah pemberian wedang jahe dalam kategori nyeri ringan $(80 \%)$.

3. Rerata Frekuensi Mual dan Muntah Sebelum dan Sesudah diberikan Wedang Jahe

Tabel 3. Rerata Frekuensi Mual dan Muntah Sebelum dan Sesudah diberikan Wedang Jahe di Kabupaten Bengkulu Utara Tahun 2017

\begin{tabular}{cccccc}
\hline $\begin{array}{c}\text { Frekuensi Mual dan } \\
\text { Muntah }\end{array}$ & Mean & $\begin{array}{c}\text { Selisih } \\
\text { Mean }\end{array}$ & SD & Min & Max \\
\hline Sebelum Intevensi & 9,30 & - & 3,129 & 5 & 14 \\
\hline Sesudah Intervensi & & & & & \\
• Hari 1 & 8,60 & 0,70 & 3,026 & 5 & 13 \\
- Hari 2 & 7,60 & 1.00 & 2,547 & 4 & 12 \\
- Hari 3 & 6,70 & 0,90 & 2,497 & 4 & 12 \\
- Hari 4 & 4,50 & 2,20 & 1,841 & 3 & 8 \\
\hline Rata-Rata & 6,85 & & 1,748 & 4,5 & 8,6 \\
\hline
\end{tabular}

Berdasarkan tabel 3 di atas, dapat disimpulkan bahwa dari 10 responden yang diberikan intervensi wedang jahe, didapatkan hasil rata-rata frekuensi mual dan muntah sebelum intervensi adalah 9,30 dan rata-rata frekuensi mual muntah sesudah intervensi adalah 6,85. Dan penurunan frekuensi mual muntah terjadi pada hari 3 ke hari 4 dengan rata-rata sebesar 2,20. Sedangkan untuk 
penurunan sebelum dilakukan intervensi wedang frekuensi mual dan muntah pada ibu hamil jahe dan sesudah diberikan sampai hari ke-4, trimester I yang mengalami emesis gravidarum. menunjukkan penurunan yang signifikan dengan rata-rata sebesar 4,80. Dapat disimpulkan 4. Analisis Bivariant pemberian wedang jahe dapat menurunkan

Tabel 4. Efektivitas Wedang Jahe terhadap terhadap Frekuensi Mual dan Muntah pada Ibu Hamil Trimester I di Kabupaten Bengkulu Utara Tahun 2017

\begin{tabular}{cccccc}
\hline $\begin{array}{c}\text { Frekuensi Mual dan } \\
\text { Muntah }\end{array}$ & N & Mean & MMean & SD & p value \\
\hline Sebelum & 10 & 9,30 & 2,45 & 3,129 & 0,000 \\
\hline Sesudah & 10 & 6,85 & & 1,748 & \\
\hline
\end{tabular}

Berdasarkan tabel 4 di atas, dapat disimpulkan bahwa terdapat perbedaan rata-rata frekuensi mual muntah sebelum dan sesudah intervensi wedang jahe sebesar 2,45 dengan $p$ value $=$
0,000, yang artinya pemberian wedang jahe efektif dalam mengurangi frekuensi mual dan muntah pada ibu hamil trimester I di Kabupaten Bengkulu Utara Tahun 2017.

Tabel 5. Analisis Pengaruh Umur, Pendidikan, Pekerjaan dan Umur Kehamilan terhadap Frekuensi Mual Muntah pada Ibu Hamil Trimester I di Kabupaten Bengkulu Utara Tahun 2017

\begin{tabular}{|c|c|c|c|c|c|c|c|c|c|}
\hline \multirow{3}{*}{ Variabel } & \multicolumn{6}{|c|}{ Frekuensi Mual Muntah (Emesis) } & \multirow{2}{*}{\multicolumn{2}{|c|}{ Total }} & \multirow{3}{*}{$p$-value } \\
\hline & \multicolumn{2}{|c|}{$\begin{array}{l}\text { Emesis } \\
\text { Ringan }\end{array}$} & \multicolumn{2}{|c|}{$\begin{array}{l}\text { Emesis } \\
\text { Sedang }\end{array}$} & \multicolumn{2}{|c|}{$\begin{array}{c}\text { Emesis } \\
\text { Berat }\end{array}$} & & & \\
\hline & $\mathbf{F}$ & $\%$ & $\mathbf{F}$ & $\%$ & $\mathbf{F}$ & $\%$ & $\mathbf{F}$ & $\%$ & \\
\hline Umur & & & & & & & & & \\
\hline $\begin{array}{l}<20 \text { tahun dan } \\
>35 \text { tahun }\end{array}$ & 1 & 76.9 & 0 & 23.1 & 0 & 0 & 1 & 100 & 0.598 \\
\hline 20-35 tahun & 7 & 77,8 & 2 & 22.2 & 0 & 0 & 9 & 100 & \\
\hline Pendidikan & & & & & & & & & \\
\hline Rendah & 3 & 100 & 0 & 27.3 & 0 & 0 & 3 & 100 & 0.201 \\
\hline Tinggi & 5 & 71,4 & 2 & 28,6 & 0 & 0 & 7 & 100 & \\
\hline Pekerjaan & & & & & & & & & \\
\hline Tidak Bekerja & 5 & 71,4 & 2 & 28,6 & 0 & 0 & 7 & 100 & 0.201 \\
\hline Bekerja & 3 & 80 & 0 & 0 & 0 & 0 & 3 & 100 & \\
\hline $\begin{array}{l}\text { Umur } \\
\text { kehamilan }\end{array}$ & & & & & & & & & \\
\hline 4-8 minggu & 4 & 100 & 0 & 0 & 0 & 0 & 4 & 100 & 0,297 \\
\hline 8-12 minggu & 4 & 66,7 & 2 & 33,3 & 0 & 0 & 6 & 100 & \\
\hline
\end{tabular}


Berdasarkan tabel 5, analisis pengaruh umur, pendidikan, pekerjaan dan umur kehamilan dengan uji chi-square. Hasil penelitian menunujukkan bahwa ada perbedaan rata-rata frekuensi mual muntah sebelum dan sesudah intervensi wedang jahe sebesar 2,45 dengan $p$ value $=0,000$. Dapat disimpulkan, pemberian wedang jahe efektif dalam mengurangi frekuensi mual dan muntah pada ibu hamil trimester I di Kabupaten Bengkulu Utara Tahun 2017.

a. Frekuensi Mual dan Muntah Sebelum dan Sesudah diberikan Wedang Jahe

Hasil penelitian ini menunjukkan presentase tertinggi frekuensi mual dan muntah sebelum dilakukan pemberian wedang jahe berada dalam kategori emesis sedang yaitu sebesar (60\%) dari ibu hamil trimester 1 yang mengalami mual muntah. Sedangkan rata-rata frekuensi mual muntah sebelum dilakukan pemberian wedang jahe adalah 9,30. Frekuensi mual muntah yang dirasakan ibu hamil trimester 1 sebelum dilakukan intervensi mengalami peningkatan dalam kategori emesis sedang. Frekuensi mual muntah meningkat karena ibu hamil masih belum mengetahui penanganan yang baik dan benar untuk mengurangi mual dan muntah (emesis gravidarum) yang sedang dialaminya serta belum ada sosialisasi yang optimal dalam penanganan emesis gravidarum.

Emesis gravidarum merupakan mual muntah yang muncul pada empat minggu pertama kehamilan dan perlahan menghilang pada umur kehamilan menginjak dua belas minggu
(Purwaningsih, 2010). Mual merupakan kecendrungan memuntahkan sesuatu, atau sensasi yang muncul pada daerah kerongkongan atau epigastrik tanpa diikuti dengan muntah, sedangkan muntah didefinisikan sebagai pengeluaran isi lambung melalui mulut, dan umumnya disertai dengan dorongan yang kuat yang terjadi pada kehamilan (Setiawan, 2012).

Penanganan emesis gravidarum dibagi menjadi farmakologi dan non farmakologi. Penanganan secara farmakologi terdiri dari pemberian Vitamin yang (vitamin B kompleks, mediamer N6 sebagai vitamin dan anti muntah) dan pengobatan sedatif ringan. Penanganan non farmakologi untuk mengatasi emesis gravidarum misalnya dengan cara memberikan teh panas (Bandiyah, 2009) dan memberikan jahe (Setiawan, 2012).

Setelah dilakukan pemberian wedang jahe, sebagian besar berada dalam kategori emesis ringan yaitu sebesar (80\%) dari ibu hamil trimester 1 yang mengalami mual muntah. Sedangkan rata-rata frekuensi mual muntah sesudah dilakukan pemberian wedang jahe adalah 6,85. Hasil penelitian menunjukkan adanya penurunan rata-rata frekuensi mual dan muntah setelah diberikan wedang jahe sebesar 2,45 .

Penurunan frekuensi mual muntah terjadi pada hari 3 ke hari 4 dengan rata-rata penurunan sebesar 2,20. Sedangkan untuk penurunan sebelum dilakukan intervensi wedang jahe dan sesudah diberikan sampai hari ke-4, menunjukkan penurunan yang signifikan 
dengan rata-rata sebesar 4,80. Dapat disimpulkan pemberian wedang jahe dapat menurunkan frekuensi mual dan muntah pada ibu hamil trimester I yang mengalami emesis gravidarum.

Hal ini sejalan dengan penelitian yang dilakukan oleh putri dkk (2017) yaitu rata-rata frekuensi morning sickness sebelum diberikan minuman jahe hangat yaitu sebanyak 13 kali dan setelah diberikan menurun menjadi 3,18 kali. Hasi uji bivariabel menunjukkan bahwa minuman jahe hangat efektif dalam mengurangi morning sickness pada ibu hamil $(p=0,000)$

Sesuai dengan manfaat wedang jahe yang dapat mengendurkan dan melemahkan otototot saluran pencernaan sehingga mual dan muntah dapat berkurang (Glare et al, 2011 dan Perwitasari et al, 2011). Dan sesuai dengan penelitian yang dilakukan oleh Putri, dkk (2017) sebelum diberi intervensi rata-rata responden mengalami frekuensi mual muntah sebanyak 13 kali dalam sehari, setelah diberi intervensi minuman jahe hangat rata-rata frekuensi mual muntah menurun menjadi 3,18 kali dalam sehari. Pada data penelitian ini sudah dilakukan uji normalitas yaitu dengan Shapiro Wilk yang hasilnya adalah data berdistribusi normal, sehingga dapat dilanjutkan untuk uji paired t-test.

\section{b. Efektifitas Pemberian Wedang Jahe terhadap Penurunan Frekuensi Mual dan Muntah}

Berdasarkan hasil analisis dengan Chi Square, frekuensi mual muntah setelah dilakukan pemberian wedang jahe, ada 2 responden $(22,2 \%)$ tetap mengalami emesis sedang yaitu pada kategori umur 20-35 tahun, 2 responden $(28,6 \%)$ tetap mengalami emesis sedang yaitu pada kategori pendidikan tinggi, 2 responden $(28,6 \%)$ tetap mengalami emesis sedang yaitu pada kategori ibu dengan tidak bekerja dan 2 responden $(33,3)$ tetap mengalami emesis sedang pada kategori umur kehamilan 8-12 minggu.

Berdasarkan hasil analisis bivariat dengan menggunakan Independent Sampel T-test, menunujukkan ada perbedaan rata-rata frekuensi mual muntah pada ibu hamil trimester 1 sebelum dan sesudah pemberian wedang jahe sebesar 2,45 dengan $p$ value $=$ 0,000 . Sehingga dapat disimpulkan pemberian wedang jahe efektif dalam menurunkan frekuensi mual dan muntah pada ibu hamil trimester 1 di Kabupaten Bengkulu Utara Tahun 2017.

Hasil penelitian ini sejalan dengan penelitian yang dilakukan oleh Saswita dkk (2011) yang menyatakan bahwa penurunan rata-rata mual dan muntah sebelum diberikan intervensi sebesar 3,87 dan setelah diberikan intervensi 2,78 dengan $p$ value 0,014. Dapat disimpulkan bahwa jahe efektif dalam mengurangi mual dan muntah selama kehamilan trimester pertama

Riset yang dilakukan oleh Universitas Chiang Mai di Thailand juga membuktikan keefektifan khasiat jahe pada ibu hamil dalam mengatasi mual muntah. Dalam riset ini melibatkan 32 ibu hamil yang mengalami mual muntah yang 
diberikan suplemen yang mengandung 1 gram ekstrak jahe setiap hari, ternyata hasilnya sangat memuaskan dimana terjadi penurunan gejala mual muntah yang signifikan pada ibuibu hamil tersebut (Hasanah, 2014).

Jahe berkhasiat sebagai anti muntah dan dapat digunakan para ibu hamil mengurangi morning sickness. Penelitian menunjukkan bahwa jahe sangat efektif menurunkan metoklopamid senyawa penginduksi mual dan muntah. Jahe putih kecil memiliki kandungan minyak atsirinya lebih besar dari pada jahe gajah, sehingga rasanya lebih pedas, disamping seratnya tinggi dan sering ditemukan dipasaran, sehingga jahe dapat dijadikan sebagai pengobatan alternatif untuk mengatasi emesis gravidarum sebelum menggunakan obat antiemetik. Kandungan wedang jahe aman dari bahan berbahaya karena dapat dibuat sendiri sehingga ibu hamil tidak perlu khawatir akan membahayakan kehamilan dan janinnya (Putri dkk, 2017).

Mekanisme jahe memiliki efek langsung dalam saluran pencernaan dengan meningkatkan pergerakan lambung, serta absorbsi racun dan asam. Jahe dipercaya sebagai pemberi perasaan nyaman dalam perut sehingga dapat mengatasi mual muntah karena kandungan minyak Atsiri Zingiberena, Zingiberol, Bisabilena, Kurkuman, Gingerol, Flandrena, vit A dan resin pahit. Kandungan zat-zat tersebut dapat memblok serotonin yaitu suatu neurotransmitter sistem saraf pusat dan sel-sel enterokromafin dalam saluran pencernaan dengan menghambat induksi HCG ke lambung.
Menurut peneliti Smith (2004) Seorang professor obstetrics dan gynecology Univeristas Adelaide, Australia menyebutkan dari hasil penelitiannya bahwa ada efek menguntungkan dari minum jahe bagi wanita karena jahe dapat mengurangi rasa mual dan muntah, bahwa jahe berkhasiat mengendurkan dan melemahkan otot-otot pada saluran pencernaan sehingga mual muntah banyak berkurang. Hasil penelitian Smith didukung dengan penelitian Vutyavanich (2001) bahwa jahe efektif untuk mengobati gangguan pencernaan dan pencegahan gejala mual muntah. Sebuah survey yang dilakukan oleh Power et al (2001) di washington DC dalam buku Tiran (2009) menemukan bahwa dokter obstetrik lebih cenderung menyarankan wanita hamil untuk mencoba mengkonsumsi jahe sebelum meresepkan obat antiemetik (Hasanah, 2014).

Berdasarkan pengamatan peneliti dilapangan, ibu mengatakan setelah meminum wedang jahe, perut terasa hangat, mual muntah berkurang. Setelah dilihat dari pola makan, 2 responden yang tidak mengalami penurunan frekuensi mual muntah yang signifikan atau dalam kategori emesis gravidarum kategori sedang. Hal ini disebabkan karena ibu terlalu banyak mengkonsumsi makanan yang memicu timbulnya mual muntah seperti kol, mentimun, nangka, dan makanan yang berbau tajam serta berminyak dan bersantan. Menurut Khabiba (2016) jenis makanan tersebut menghasilkan gas dalam perut sebaiknya dihindari oleh ibu hamil, sebab pada ibu hamil gerakan lambung melambat dan membentuk gas sehingga 
Iluh Meta I, Rialike B, dan Desi W, Efektifitas Pemberian Wedang Jahe terhadap Frekuensi Mual dan Muntah pada Ibu Hamil Trimester I di Kabupaten Bengkulu Utara Tahun 2017

mengakibatkan perut terasa kembung serta mengiritasi lambung.

Ibu beralasan mengkonsumsi makanan tersebut karena faktor ngidam yang terlalu berlebihan sehingga tidak dapat menghindari meskipun mual muntah terus menerus, ibu juga mengalami gangguan istirahat (tidak pernah tidur siang) dikarenakan peran ibu sebagai wanita mengurus anak dan rumah tangga. Faktor tersebut sebagai salah satu pemicu tidak ada penurunan frekuesi mual muntah secara signifikan

Berdasarkan hasil penelitian dan teori di atas dapat disimpulkan bahwa pemberian wedang jahe pada ibu hamil trimester 1 yang mengalami mual dan muntah (emesis gravidarum) memegang peranan penting dalam pemberian asuhan kebidanan yang dapat membantu menurunkan frekuensi mual dan muntah dalam kehamilan. Untuk mewujudkan terlaksananya intervensi pemberian wedang jahe, diperlukan adanya kerja sama dan kesadaran yang tinggi dari bidan dan ibu hamil. Kemampuan ibu dalam menerapkan penanganan non farmakologi selama mual muntah dalam kehamilan yaitu dengan pemberian wedang jahe tidak dapat dipisahkan dari pengetahuan ibu. Oleh karena itu, bidan harus mampu memberikan konseling cara mengurangi mual dan muntah yaitu dengan pemberian wedang jahe saat mengalamai emesis gravidarum, tidak hanya memberikan obat-obatan untuk mengurangi mual muntah.

\section{SIMPULAN}

Terdapat perbedaan rata-rata frekuensi mual muntah sebelum dan sesudah intervensi wedang jahe sebesar 4,80 dengan $p$ value $=$
0,000, yang berarti pemberian wedang jahe efektif dalam mengurangi frekuensi mual dan muntah pada ibu hamil trimester I di Kabupaten Bengkulu Utara tahun 2017.

\section{DAFTAR RUJUKAN}

Bandiyah. 2009. Kehamilan Persalinan Gangguan Kehamilan. Nuha Medika. Yogyakarta

Dinas Kesehatan Kabupaten Bengkulu Utara. 2016. Profil Dinas Kesehatan Kabupaten Bengkulu Utara. Bengkulu

Hasanah. 2014. Efektivitas Pemberian Wedang Jahe (Zingiber Officinale Var. Rubrum) terhadap Penurunan Emesis Gravidarum pada Trimester Pertama. Jurnal Biometrika dan Kependudukan Vol. 3 No. 1 Halaman 81-87

Irianto, Koes. 2015. Kesehatan Reproduksi Reproductive Health Teori \& Praktikum. Alfabeta. Bandung

Manuaba IGB. 2012. Ilmu Kebidanan, Penyakit Kandungan dan KB Untuk Pendidikan Bidan. Penerbit Buku Kedokteran EGC. Jakarta

Marianti dkk. 2014. Hubungan Dukungan Suami, Usia Ibu dan Gravida terhadap Kejadian Emesis Gravidarum. JOM PSIK Volume 1 Nomor 2 Halam 1-9

Purwaningsih. 2010. Asuhan Keperawatan Maternitas. Yogyakarta. Nuha Medika

Putri, dkk. 2017. Efektifitas Pemberian Jahe Hangat dalam Mengurangi Frekuensi Mual Muntah pada Ibu Hamil Trimester I. Naskah Publikasi. Fakultas Ilmu Kesehatan, Universitas Muhammadiyah Parepare

Rinata, dkk. 2015. Penanganan Emesis Gravidarum Pada Ibu Hamil Di BPM Nunik Kustantinna Tulangan Sidoarjo. Naskah Publikasi. Program Studi Diploma III 
211 Jurnal Ilmu dan Teknologi Kesehatan, Vol 5 Nomor 2, Maret 2018, hlm : 201-211

Kebidanan Fakultas Ilmu Kesehatan Universitas Muhammadiyah Sidoarjo

Saswita dkk. 2011. Efektifitas Minuman Jahe dalam Mengurangi Emesis Gravidarum pada Ibu Hamil Trimester I. Jumal Ners Indonesia, V o 1 . 1, No. 2, Maret 2011
Setiawan. 2012. Panduan Terapi Aman Selama Kehamilan. Surabaya. PT. ISFI Penerbitan

$\begin{array}{crr}\text { Setyaningrum. } & 2013 . & \text { Asuhan } \\ \text { Kegawatdaruratan } & \text { Maternitas } \\ \text { (Asuhan } & \text { Kebidanan } & \text { Patologi). In } \\ \text { Media } & & \end{array}$

